\title{
The Negros Ark: A Hypothesis The systematics and biogeography of Rhopalocera (Lepidoptera) in the Philippines
}

\author{
Jade Aster T. Badon*
}

\begin{abstract}
Current distributional data on Philippine butterflies suggests that colonization and exchange of species between Luzon and Mindanao are hypothesized to have occurred during the Miocene Epoch (23-5.3 million years ago). Species from the families Pieridae, Hesperiidae, and Zygaenidae were set as an example to explain some disjunction of distribution of some species in the archipelago. The hypothesis will definitely become an interest in the field of biogeographical and phylogenetic studies in the country.
\end{abstract}

KEYWORDS: butterfly, colonization, biogeography

\section{INTRODUCTION}

Baltazar (1991) published the first checklist of Philippine butterflies which provided island distribution, while Treadaway and Schroeder (2012) published a revised edition which also hypothesized the areas where butterflies may have reached the Philippines from mainland Asia and neighboring Pacific islands. Reliable information on the evolution of plants and animals from biologists are essential for the paleogeography of Sundaland and Wallacea (Hall 2013). Philippine geology remains poorly known in the relation to many other parts of Southeast Asia (Hall 2017, pers.comm.). There are eight centers of endemism in the Philippines based on butterflies and moths (Seitz 1908-1928), while six based from mammalian distribution (Heaney et al. 1998), and this was the result of land bridges during the Pleistocene Epoch.

What if there was a more ancient area of endemism in the Philippines before the Pleistocene epoch? What are the possibilities that some ancient organisms such as insects are already colonizing and dispersing from island to island aside from relying on land bridges? Phylogenetic analyses suggest

${ }^{1}$ McGuire Center for Lepidoptera and Biodiversity, Florida Museum of Natural History, University of Florida, Gainesville, Florida, USA 32611 Department of Entomology and Nematology, University of Florida, Florida, USA

${ }^{2}$ Philippine Lepidoptera Butterflies and Moths, Inc.

*Corresponding email: jaabadon@gmail.com

Date Submitted: 05 May 2018

Date Accepted: 30 January 2019 that the genus Delias (Hübner 1819) originated in Australia (Braby \& Pierce 2006), and the genus also likely to have colonized neighboring islands during the early Miocene (235.3 million years ago) (Figure 1f) and reached the Wallacea (Müller et al. 2012). Basic information on butterfly species distribution through surveys are very important in the Philippines (Cayabyab et al. 1994; Cayabyab et al. 2000) as well as their hostplants (Cayabyab et. al. 1993). Braby (2006) noted that larvae of Delias henningia from Palawan and Luzon are able to consume plants species belonging in both Loranthaceae and Euphorbiaceae, although, most species of Delias in the Philippines have unrecorded hostplants but they probably utilize plants in the genus Loranthus.

\section{The Negros Ark Hypothesis}

Vane-Wright (1990) discussed the position of the Philippines on the Wallacea based on the distribution of milkweed butterflies (Lepidoptera: Nymphalidae: Danainae) from Borneo, Sulawesi, and Luzon (Philippines), and concluded that there was past dispersal between the Philippines and Sulawesi and from Sulawesi to the Mollucas.

Jones and Kennedy (2008b) investigated four hypotheses of colonization and diversification of some Passeriformes (Muscicapidae) using phylogenetic analysis, and one of the hypotheses was from Mindanao-Negros-Panay-MindoroLuzon. The result of Eumyias panayensis (Muscicapidae) showed that the population of Luzon and Mindoro is closely related with Mindanao, then to Negros and Panay, although the route was not identified because of the closer 


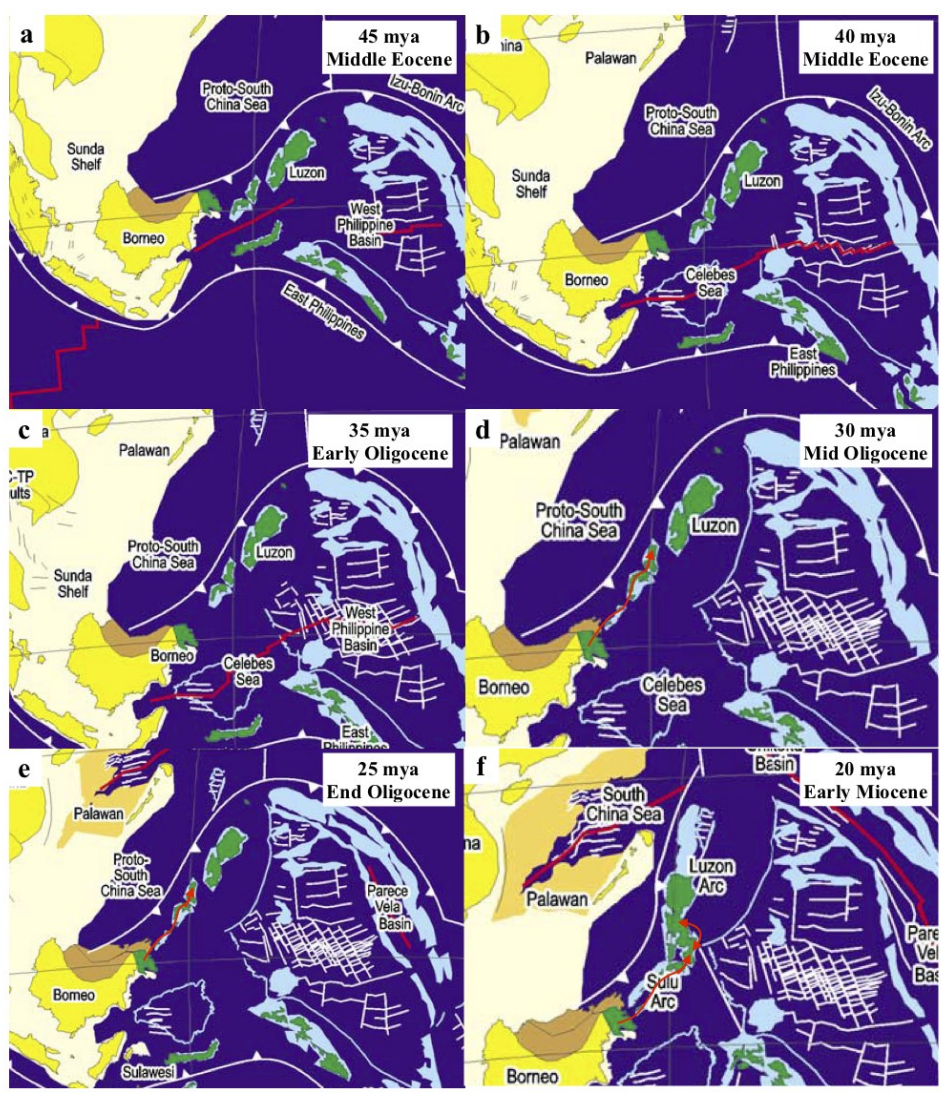

Figure 1. Major geological timeline of Southeast Asia 45 mya to 20 mya with the hypothetical route of colonization (red lines with arrows) of species from Borneo to the Negros-Zamboanga Peninsula Complex through the Sulu Archipelago. Maps from Hall (2002) with slight modifications and with permission to use the maps.

association among Luzon, Mindoro, and Mindanao (Jones \& Kennedy 2008a). It is more likely that the species arrived from Sulawesi to Mindanao then through the Negros Ark which provided the opportunity for the species to disperse in Luzon, and then back to Mindanao, while some populations in Negros and Panay got isolated when Negros island detached from Zamboanga Peninsula.

There are currently 927 species of butterflies in the country and one-third are endemic (Treadaway \& Schroeder 2012). How did the Philippines produce so many endemic species in a small land area? The answer likely lies in having many islands of various sizes and ages. Island-specific colonization and isolation undoubtedly contributed to the endemicity of the archipelago's butterflies. Speciation can result from varied geographic and ecological scenarios (Rosenzweig 1995), and allopatric speciation is generally thought to be the most common mode of speciation in animals and is most likely responsible for much endemic Philippine biodiversity.

Geological dynamism resulting in the formation and movement of Philippine islands have contributed to the colonization of butterfly species from Sundaland. The

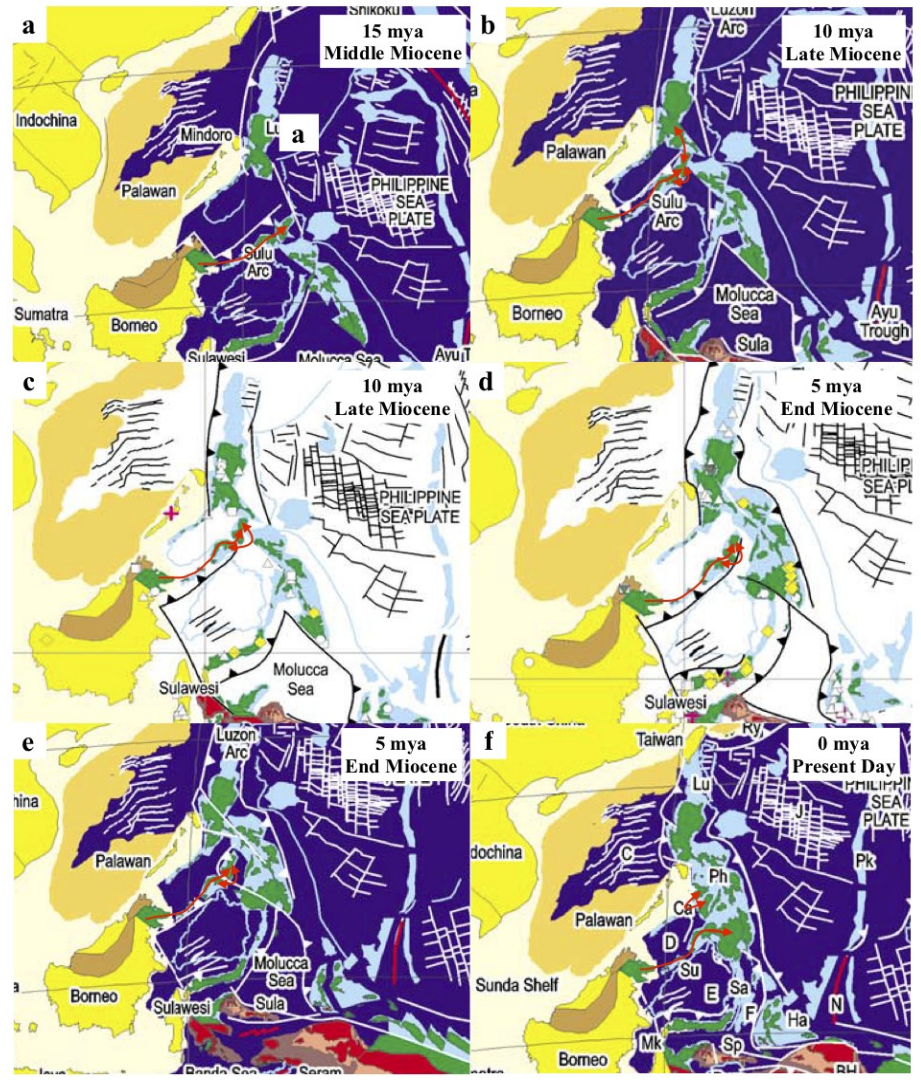

Figure 2. Major geological timeline of Southeast Asia 15 mya to 0 mya with the hypothetical route of colonization (red lines with arrows) of species from Borneo to the Negros-Zamboanga Peninsula Complex through the Sulu Archipelago. Maps from Hall (2002) with slight modifications and with permission to use the maps.

hypothesis described here is based on the analysis of species distributions of Philippine butterflies and the recent molecular phylogenetic studies of Delias by Braby and Pierce (2006) and other taxa such as birds by Jones and Kennedy (2008a; 2008b) that may support past dispersal from other areas into the Philippines. Consideration of this work leads me to posit an unappreciated role for Negros in Philippine zoogeography.

This hypothesis can provide a baseline for further research on Philippine biogeography, but the massive habitat destruction and climate change could affect current butterfly distribution in the Philippines. Therefore, the paper would follow Treadaway and Schroeder's checklist (2012) which provided the first distributional records of all known subspecies in the country. The movements of NegrosZamboanga Peninsula Complex during the formation of the Philippine islands may have contributed to the dispersal and colonization of species to Negros and Luzon and from Luzon to Negros and Mindanao. Further research is needed especially for Negros and Panay in their roles in dispersal and vicariance (Jones \& Kennedy 2008b). Species of Delias occurring in the Philippines are also illustrated to provide a 
photographic checklist.

"The Negros Ark Hypothesis posits that the island of Negros may have facilitated the movement and colonization of species between Mindanao and Luzon and vice versa"

Some species of Philippine butterflies are found both in Luzon and Mindanao but not in the islands in between, this is a similar case with Balabac Island, wherein it is situated between Borneo and Palawan, but some species that are recorded in both islands are not in Balabac Island.

\section{Distributional Data Supporting The Negros Ark Hypothesis}

Several publications were reviewed to support the hypothesis especially the publications of Treadaway and Schroeder's (2012) on the checklist of Philippines butterflies, Hall's (2002 \& 2013) landmark paper on the origin and biogeography of Southeast Asia (Hall's 1996 reconstruction has been treated as "intriguing" by Treadaway \& Schroeder 2012), the Illustrated Checklist of Delias of the World by Yagishita et al. (1993), d'Abrera's volumes of the Butterflies of the Oriental Region (1982), and Tsukada's volumes (1985) on the Butterflies of Southeast Asian Islands. The perfect model for the hypothesis is the butterfly genus Delias, since most species in the Philippines are endemic to islands and mostly found on mountains, and their origins are most likely from Borneo. Butterfly species from other butterfly families and other taxa such as birds and a moth were also included to provide support for the hypothesis.

Delias baracasa Semper 1890 (Lepidoptera: Pieridae) (Plate 1f-i) is currently known from Mindanao (ssp. baracasa Semper 1890), Basilan (ssp. basilana Schroeder \& Treadaway 2008), and North Luzon (ssp. benguetana Inomata 1979). The species occurs in the north and south, but not in the islands in between. Since this species occurs in Borneo, this species may have dispersed to Basilan first then to Luzon through the Negros Ark Hypothesis, which few individuals colonized or dispersed to Luzon and established a new subspecies when it became isolated when the $N-Z$ (Negros-Zamboanga) complex drifted southwards joining the larger part of Mindanao.

Delias georgina (C. \& R. Felder 1861) (Plate 3e-f) is a species found only in the northern regions of Luzon. This species looks very similar to $D$. ganymedes (Plate $3 \mathrm{~b}-\mathrm{d}$ ), $D$. schoenigi (Plate $3 \mathrm{~g}-\mathrm{I}$ ), and $D$. paoaiensis (Plate 1I) (Figure 3a). The origins of these species may have been from North Borneo, where individuals of $D$. georgina cinerascens Mitis 1893 dispersed to the Philippines through the Sulu Archipelago, and then the Negros-Zamboanga complex. When the $\mathrm{N}-\mathrm{Z}$ complex collided with Luzon during Late Miocene 10-15 mya, some individuals may have dispersed towards the island (Luzon) and colonized the northern regions, which eventually developed into a new subspecies, D. g. georgina. D. ganymedes is currently distributed in the islands of Negros, Panay, and interestingly, to Mindoro island, and $D$. ganymedes may have diverged from the isolated populations of $D$. georgina when the complex moved further southwards.

Then the isolated $D$. georgina in the Zamboanga Peninsula may have given rise to a new species (through divergence), $D$. schoenigi which is currently found on the mountains of Mindanao. The several mountain ranges of northern Luzon may have been the reason for the divergence of $D$. paoaiensis from common ancestor with $D$. georgina. Same with $D$. nuydaorum in Mindanao which they may have diverged from common ancestor with $D$. schoenigi and $D$. magsadana. The route of some Delias from Borneo to Mindanao, to Negros, and towards Luzon in similar to routes of the bird Elegant Tit (Periparus elegans) from a study by Jones and Kennedy (2008a).

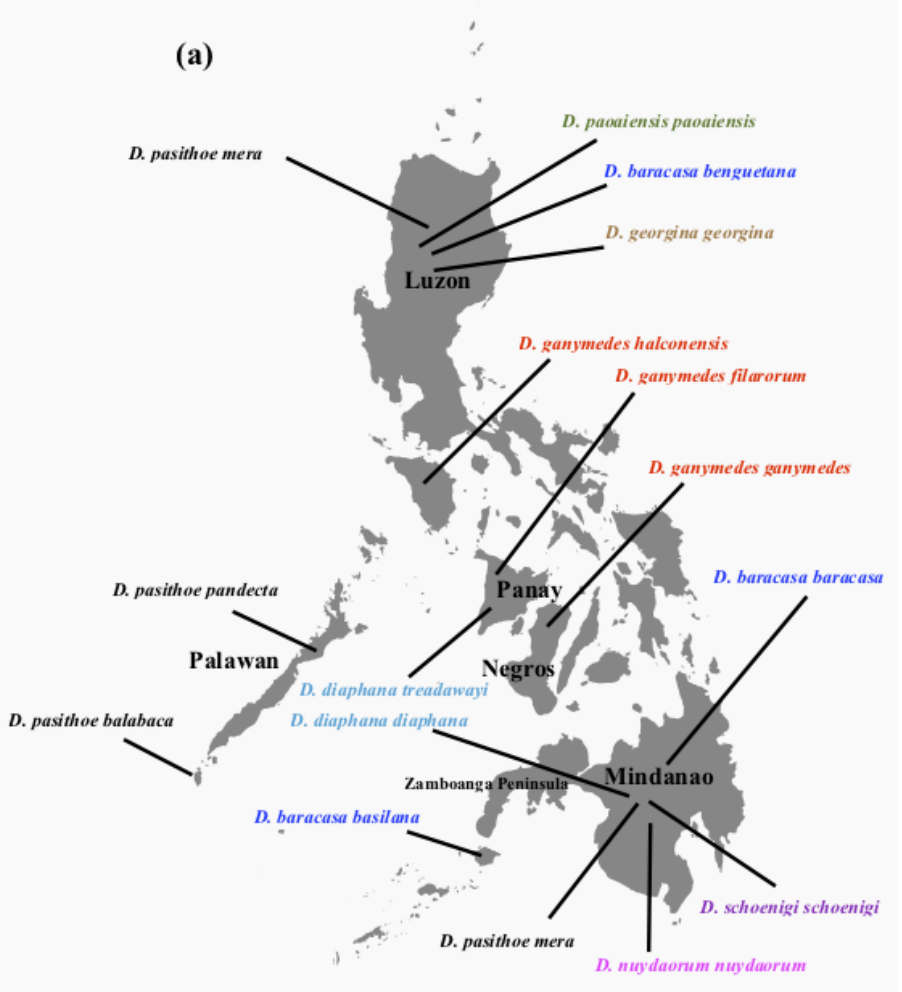

Figure 3. Distributional map of selected Delias spp. (in colors) in the Philippines.

Delias blanca (C. \& R. Felder 1862) (Plate 1p-q) is currently distributed in the islands of Luzon, Negros, Bohol, and Mindanao, and D. b. nausicaa Fruhstorfer 1899 is distributed in northern Borneo. From Borneo, this species may have dispersed to the Philippines through the Sulu Archipelago and may have landed first in Zamboanga Peninsula and then to Negros Island (Negros Ark Hypothesis), which some individuals got dispersed toward Luzon through the $\mathrm{N}-\mathrm{Z}$ complex. When Negros and 


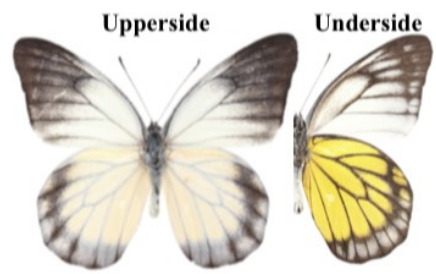

(a)

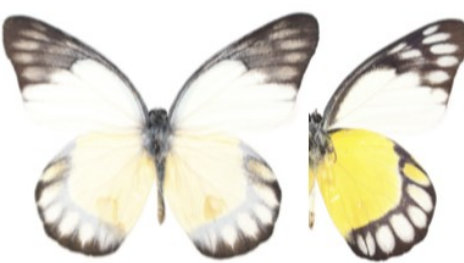

(d)

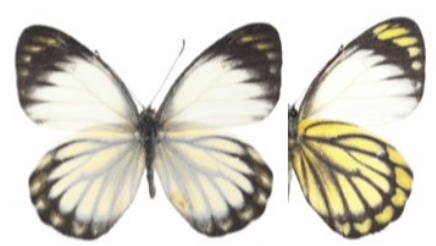

(g)

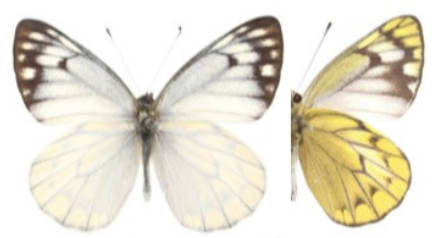

(j)

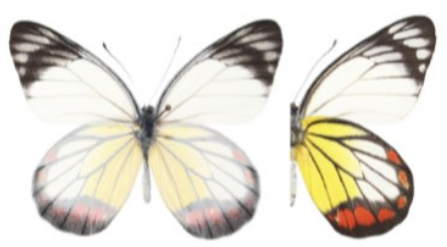

(m)

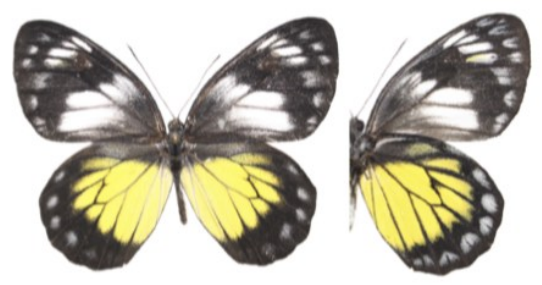

(p)

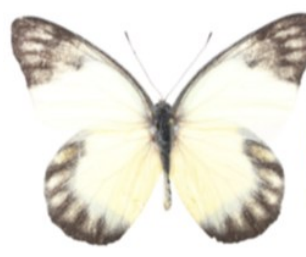

(b)

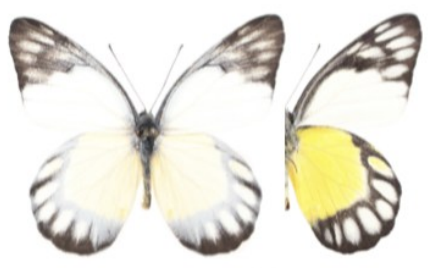

(e)

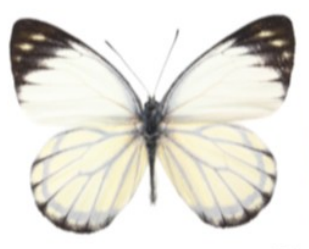

(h)

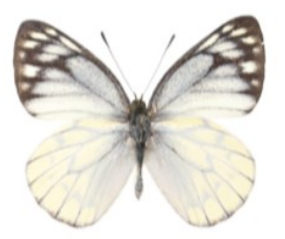

(k)

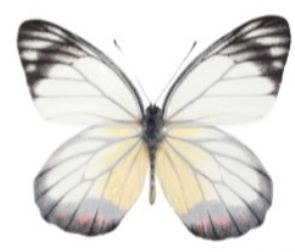

(n)
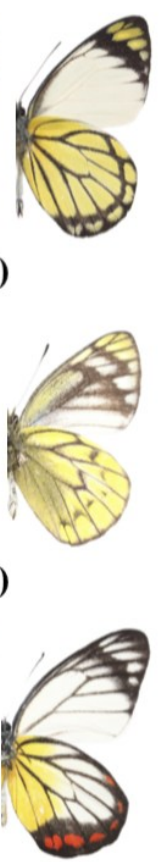

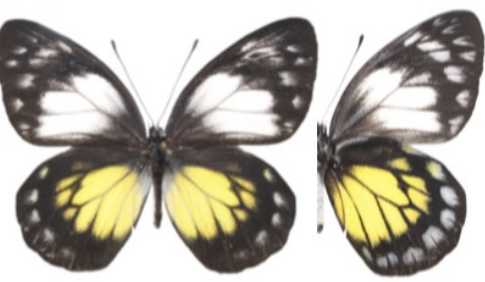

(q)

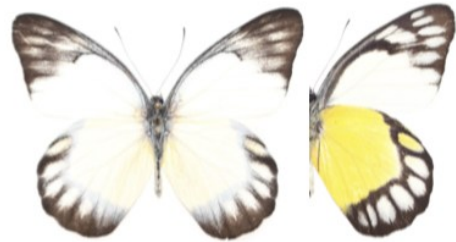

(c)

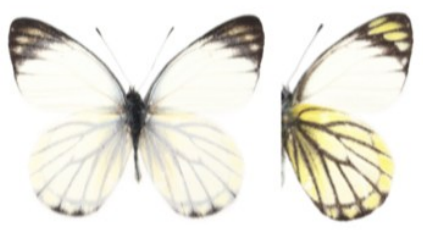

(f)

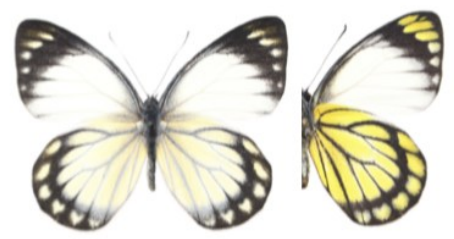

(i)

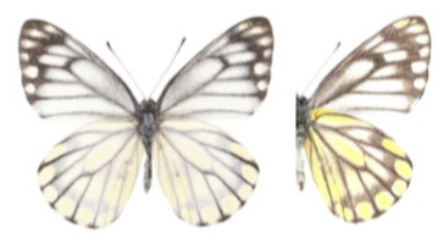

(I)

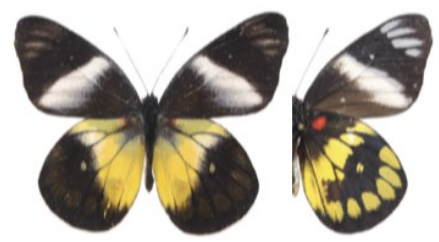

(o)

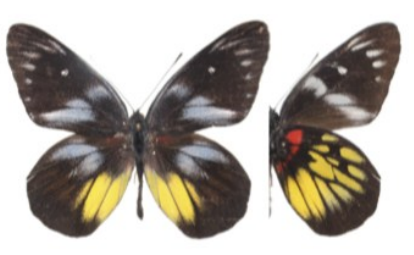

(r)

Plate 1. (a) Delias singhapura indisticta (ơ), Borneo (February), (b) Delias themis themis ( $\left.0^{r}\right)$, South Mindanao (October), (c) Delias themis kawamurai (o'), Mindoro (September), (d) Delias themis mihoae (o"), Negros (May), (e) Delias themis soteira ( $\left.0^{\prime}\right)$, Luzon (March), ( $\left.\mathrm{f}\right)$ Delias baracasa baracasa (ơ), Mindanao (March-May), (g) Delias baracasa baracasa (\%), Mindanao (May), (h) Delias baracasa benguetana ( $0^{\prime)}$, North Luzon (March), (i) Delias baracasa benguetana (\$), North Luzon (March), (j) Delias nuydaorum nuydaorum (ơ), Central Mindanao (April), (k) Delias nuydaorum tagai ( $0^{\prime)}$, South Mindanao (March-May), (I) Delias paoaiensis paoaiensis ( $0^{\natural)}$, North Luzon (June), (m) Delias hyparete luzonensis ( $0^{\prime)}$ ), Mindoro (April), (n) Delias hyparete palawanica (ơ), Palawan (March), (o) Delias woodi woodi (ơ), South Mindanao (March), (p) Delias blanca blanca (\$), North Luzon (May), (q) Delias blanca blanca (\%), Mindanao (May-July), (r) Delias hidecoae (ơ), Mindoro (August). 


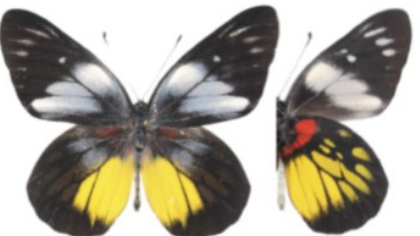

(a)

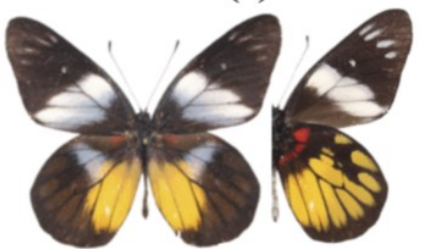

(d)

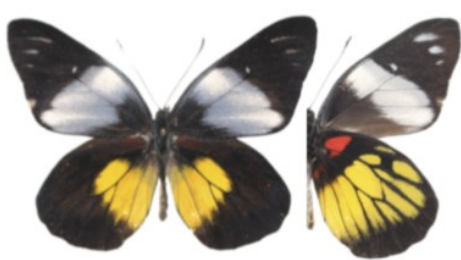

(g)

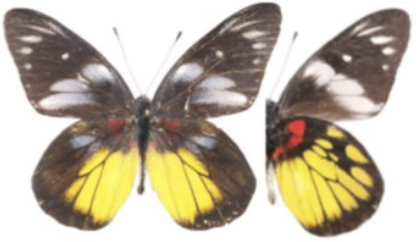

(b)

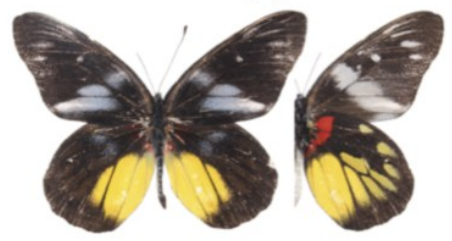

(e)

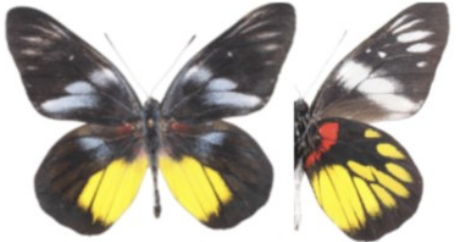

(c)

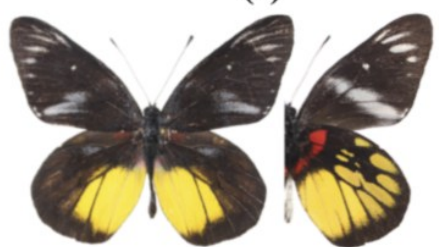

(f)

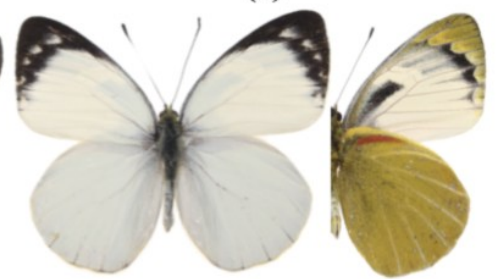

(h)

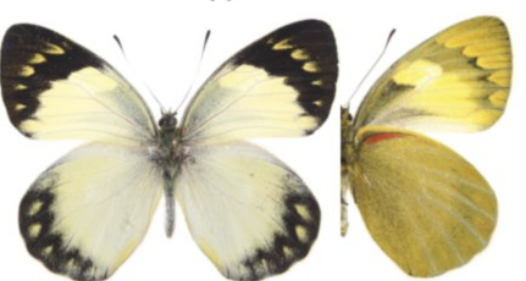

(i)

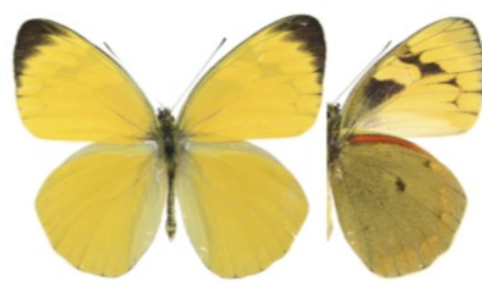

(j)

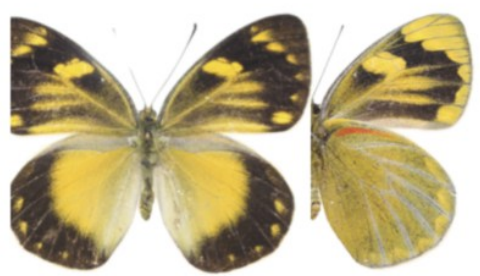

(m)

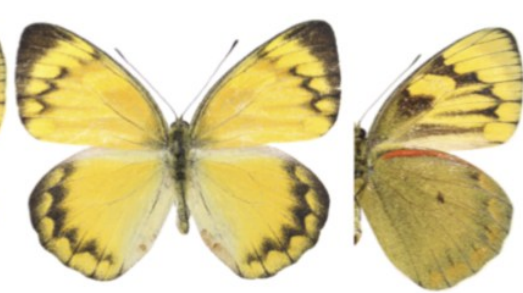

(k)

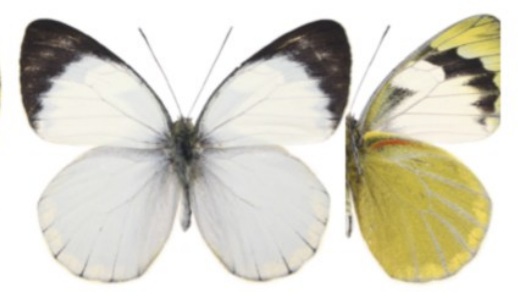

(I)

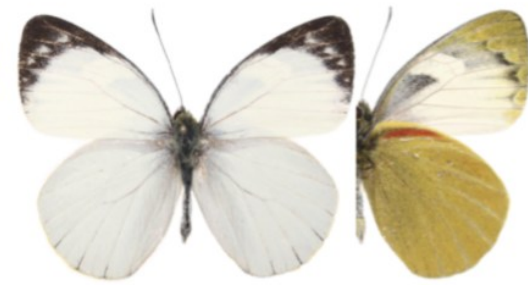

(n)

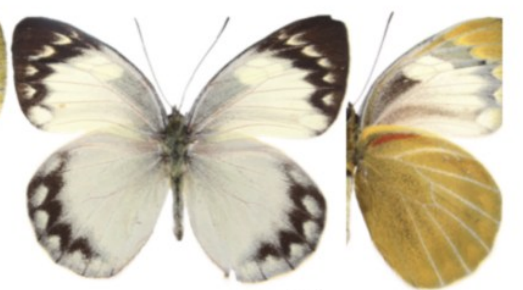

(o)

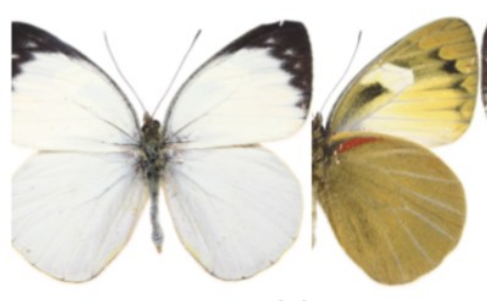

(p)

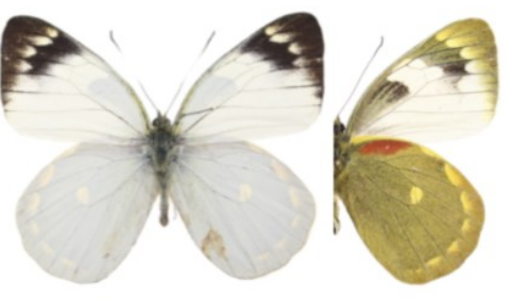

(q)

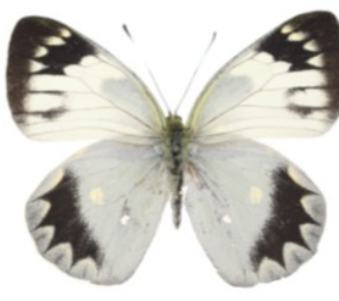

(r)

Plate 2. (a) Delias henningia henningia (ơ), Marinduque (August), (b) Delias henningia henningia (ơ), Mindoro (April), (c) Delias henningia henningia (ơ), Mindoro (April), (d) Delias henningia ochreopicta (ơ), Mindanao (March), (e) Delias henningia voconia (ơ), Bohol (February-April), (f) Delias henningia pandemia ( $\left.0^{\prime}\right)$, Palawan (May), (g) Delias ottonia ottonia (ơ), Mindanao (August), (h) Delias levicki levicki (ơ), South Mindanao (March-May), (i) Delias levicki levicki (()), South Mindanao (March-May), (j) Delias levicki mandaya (ơ), East Mindanao (February-May), (k) Delias levicki mandaya (P), East Mindanao (February-May), (I) Delias levicki borromeoi ( $\left.\sigma^{\prime}\right)$, South Mindanao (April-September), (m) Delias levicki borromeoi (९), South Mindanao (April-September), (n) Delias levicki justini (ơ), N.W. \& N. Mindanao (November), (o) Delias levicki justini (१), N.W. \& N. Mindanao (June), (p) Delias levicki hokamae (ơ), South Mindanao (January), (q) Delias apoensis apoensis ( $\left.{ }^{*}\right)$, South Mindanao (March-April), (r) Delias apoensis apoensis (१), South Mindanao (January-March). 


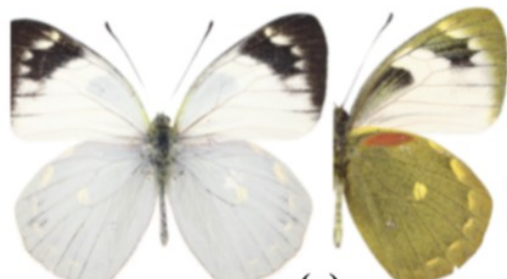

(a)

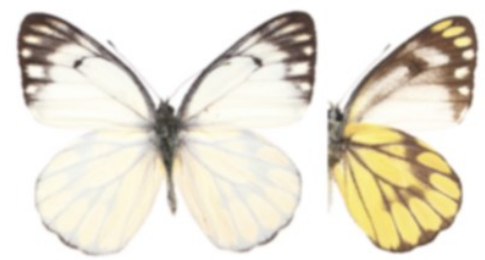

(d)

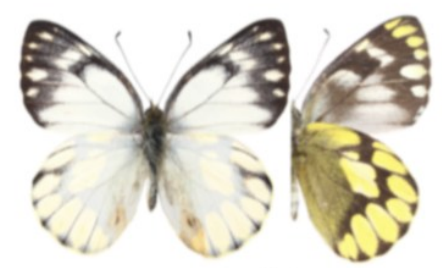

(g)

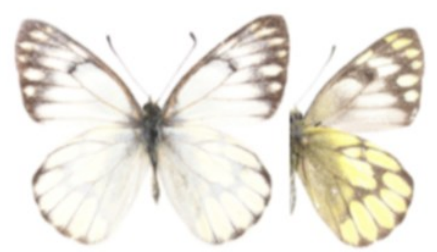

(j)

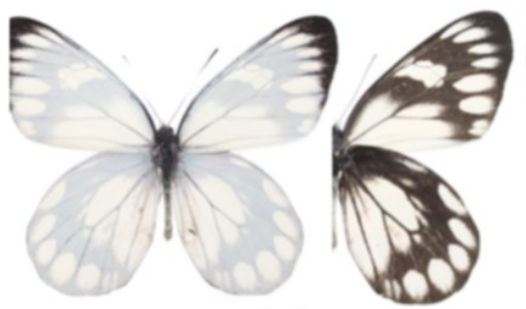

(m)

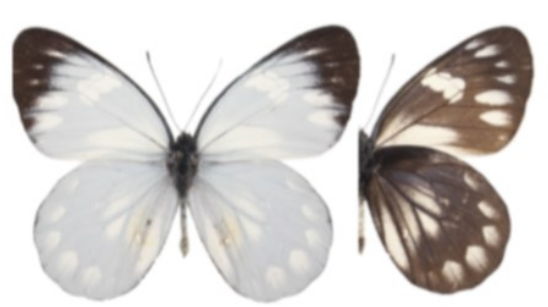

(p)

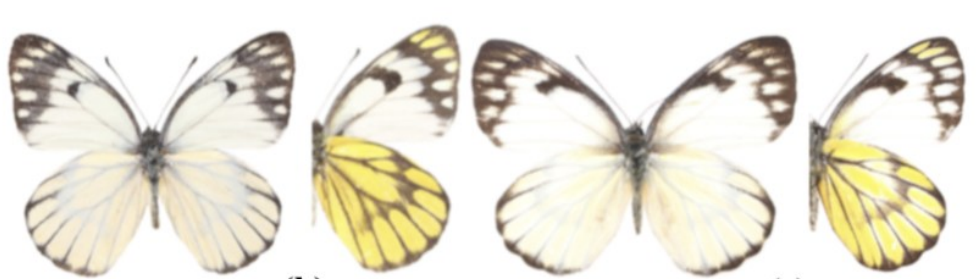

(b)

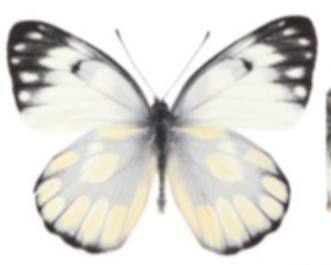

(e)
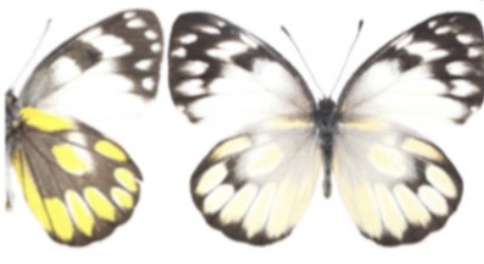

(f)

(c)

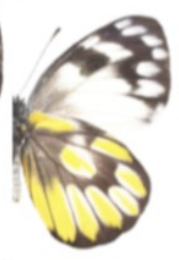

(f)

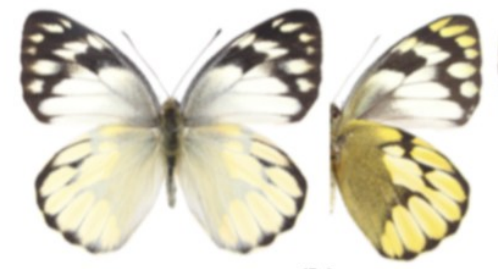

(h)

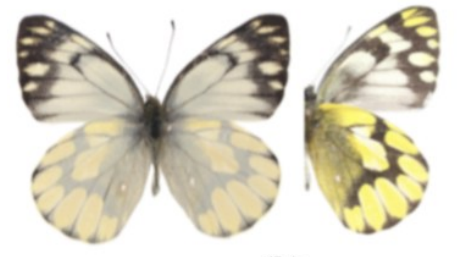

(k)

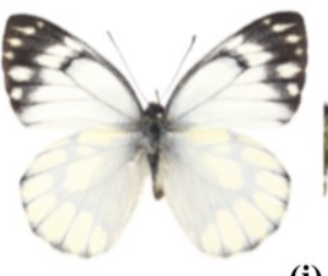

(i)

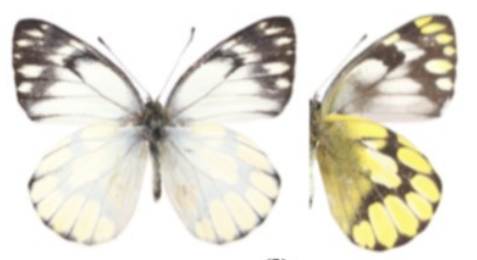

(I)

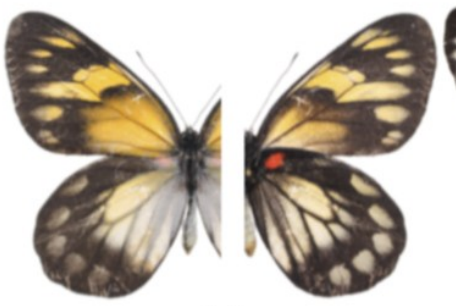

(n)

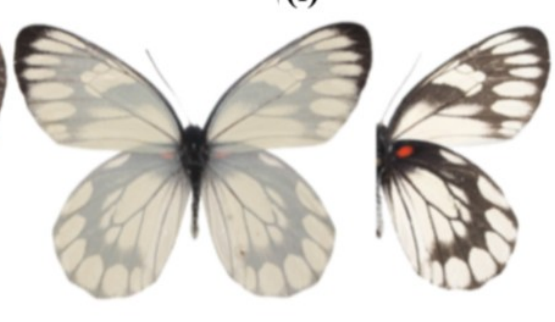

(o)

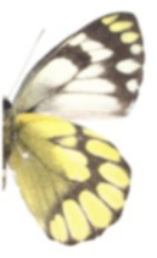




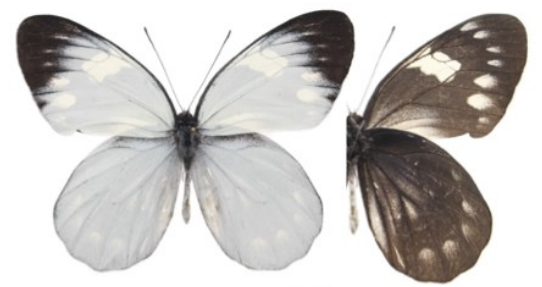

(a)

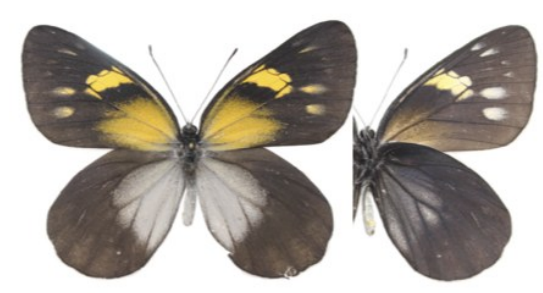

(b)

Plate 4. (a) Delias diaphana treadawayi (ơ), Panay (March-April), Paratype, (b) Delias diaphana treadawayi ()), Panay (March-April), Holotype.

Zamboanga detached (attaching to mainland Mindanao), the two populations developed into two different subspecies.

Delias pasithoe (Linnaeus 1758) may have dispersed to Balabac (D. p. balabaca Fruhstorfer 1911) Island and Palawan (D. p. pandecta Staudinger 1889) from northern Borneo. But this species is also represented in Luzon and Mindanao (D. p. mera) and the possible explanation on the occurrences of the species to both distant islands is through the Negros Ark Hypothesis.

Delias diaphana (Plate $3 \mathrm{~m}-\mathrm{r}$ \& Plate $4 a-b$ ) is an endemic species in the Philippines and it may have dispersed to Panay and Mindanao from Borneo (Delias eumolpe) via Negros Island. It was thought that $D$. diaphana is only found in Mindanao, but Badon and Jakusch (2016) described a new subspecies (Delias diaphana treadawayi) occurring on Panay Island, and the Negros Ark Hypothesis might explain this distribution. There is a possibility that this species also occurs in Negros Island. The same phenomenon is probably true with the distribution of Delias baracasa in Luzon and Mindanao.

Thoressa justini Inoue \& Kawazoe 1969 (Hesperiidae). This species is only known in the Philippines and currently distributed in Luzon and Leyte. de Jong and Treadaway (1993) noted that this species may have arrived from the Philippine through Taiwan, but Nuyda and Kitamura (1994) noted that the species may have arrived in the Philippines from the South, but de Jong and Treadaway (2007) stated that it is highly unlikely since the genus is absent from Sundaland. There is possibility that the species may have arrived in Leyte from Luzon to Negros Island and then to Mindanao, and then got dispersed to Leyte.

Gynautocera philomela Herrich-Schäffer 1853 (Lepidoptera: Zygaenidae) is a moth currently distributed in the Philippines, Sumatra, Java, Sulawesi, and the Mollucas (Endo \& Kishida 1999). In the Philippines, the ssp. philippinensis Hering 1922 is distributed in Luzon, Mindoro, and Mindanao, and currently, this species has not been recorded in Borneo. The dispersal of this species to the Philippines may have been from Borneo? and then it dispersed to the Sulu archipelago towards the NegrosZamboanga complex. Some populations may have reached Luzon (and then to Mindoro) when the $\mathrm{N}-\mathrm{Z}$ complex attached to mainland Luzon, and when the $\mathrm{N}-\mathrm{Z}$ complex and moved southwards, the rest of the population dispersed throughout Mindanao when Zamboanga Peninsula detached from Negros Island and joined the mainland Mindanao.

\section{Discussion}

There could be several explanations for this phenomenon but here are some of the possibilities: (1) the Visayas islands may have only aided dispersal and colonization but not for the settlement of the species, (2) local extinction due to several factors such as predation, climatic changes, habitat loss, etc. What do these islands have in place in metapopulation and island biogeography?

If Negros Island facilitated the colonization of butterflies around the Philippines, then the island is much more biogeographically important than previously thought. Since insects in particular are poorly studied in most of the islands, then Negros island will likely have a handful of species that are linked to both islands of Luzon and Mindanao. A major problem is the forest loss in the island wherein only $3 \%$ old growth forest cover is left of what used to be $77 \%$ around 1800s (Heaney \& Regalado 1998). There is a possibility that these species links, endemic or not, are already extinct undocumented. According to Brook et al. (2003), loss of forest in Singapore resulted in extinctions of flora and fauna including butterflies. The other possible explanation why there are not that many species of Delias on Negros Island is that there are only 3 major mountain ranges: Mount Talinis in the south, Mount Canlaon and the North Negros Natural Park in the northern region of the island. The several high mountain ranges of Mindanao may have facilitated the radiation of the genus Delias, and the uplifted corals and 
coastal cliffs around the Negros Island may provide evidences on the island's movements and inter-island collisions in the past.

According to the Theory of Island Biogeography by McArthur and Wilson (1967) and some data of area-species relationship by Rosenzweig (1995), larger islands will have more species compared to smaller islands. In the Philippines, Mindanao is the largest island and Luzon is the second, though, Treadaway and Schroeder's (2012) suggested that Luzon has slightly more species compared to Mindanao, but the latter may still have a handful of species awaiting discovery. What is the significance of the Negros Ark on the Theory of Island Biogeography and metapopulation studies? One possible answer is that it probably affected the distribution and colonization of species from two islands, and that Negros Island probably became not the just the link but also the center of endemism due to the isolated populations during the species exchange events.

Reviewing Vane-Wright's (1990) question on the significance of the Makassar Strait discontinuity, he discussed that Borneo, Luzon, and Sulawesi share some milkweed butterflies, which he also noted a statement from Balgooy (1987) the difficulty of species exchange across the Macassar strait (between Borneo and Sulawesi).

The Negros Ark hypothesis may provide a possible answer to this discontinuity and that species from Borneo reached Luzon through Negros-Zamboanga complex and then reached Sulawesi from Mindanao through Sangihe Island. Jones and Kennedy (2008a) summarized some colonization routes in other taxa and from their current studies which emphasized routes from Mindanao to Luzon through possibly Negros and vice versa.

The major island distribution of Island Thrush (Turdus poliocephalus) in the Philippines is Luzon, Mindoro, Sibuyan, Panay, Negros, and Mindanao, and based from genetic analysis, the southern populations (Panay, Negros, and Mindanao) are closely related to birds from Borneo, Sulawesi, Vanuatu, and Solomon Islands than the northern populations (Luzon, Mindoro, and Sibuyan) (Jones \& Kennedy 2008b). Based from the distribution alone, it seems that the species arrived from the south (Borneo, Sulawesi, etc.) reaching Mindanao first then towards Luzon through the Negros Ark. For the Island Thrush, there may have been multiple colonization in the Philippines especially to Mindanao and Negros (when it was attached to the Zamboanga Peninsula) and there is a possibility that one colonization event happened towards Luzon (through the Negros Ark) for the northern populations (Luzon, Mindoro, and Sibuyan). The occurrence of some species of microlepidoptera in Luzon,
Panay, and Mindanao have been questioned by Diakonoff (1967), although he added that this could also be the result of lack of knowledge (same with Semper (1886-1892) who also documented the distribution of Philippine butterflies). Townes and Chiu's (1970) work on Xanthopimpla concurred with Diakonoff's theory of reduction of depth of the seas. It might have been $600 \mathrm{ft}$ level of water below the present may have really existed, and it may even be below $600 \mathrm{ft}$ such that connections through islets in places with present deep waters may have existed. Hence, there was free exchange of faunal butterflies between the Pleistocene period's low water level of the seas and this partly explains the new records of butterflies in Mt. Makiling, Los Banos, Laguna that where invariably reported from the Visayas, Mindoro, Mindanao, and Palawan (Cayabyab 1992). Therefore, There is still a need to further investigate the insect colonization and dispersal events before the Pleistocene in the Philippines, since they may provide more answers on the routes of species colonization to the archipelago from neighboring areas such as mainland China, Borneo, North Sulawesi, and West Papua.

The Philippines can be considered as the crossroad of the Wallacea probably due to species exchanges through the movements of its islands and extinction events (which probably explains the disjunction in distribution) due to smaller land areas. The biogeography of the Philippines will always be an interesting topic, and the insects in the country will probably illuminate some answers since they (insects) are one of the most primitive organisms in the planet. The entomological fauna of the Philippines will become an avenue for phylogenetic and biogeographic studies in the future.

\section{ACKNOWLEDGEMENTS}

I am indebted and thankful to my adviser Thomas C. Emmel, Ph.D. who provided the support for my graduate studies in the University of Florida. To Mr. Colin G. Treadaway, F.R.E.S., whom we had a great conversation about his expeditions in the Philippines and his great publications of the butterfly fauna of the country. To David Lohman, Ph.D. of College University New York and Andrew D. Warren, Ph.D. of the McGuire Center for Lepidoptera and Biodiversity, for reviewing this paper and providing important comments and suggestions. To Robert Hall of Royal Holloway University of London, U.K., for his insights on the biogeography Southeast Asia and also for allowing me to use some of his maps for this paper.

I would like to thank Andrei Sourakov, Ph.D. and Andrew Warren, Ph.D. who helped me in my work in the collections room (especially Jens Jakusch Collection) of the McGuire 
Center and Lepidoptera and Biodiversity, Florida Museum of Natural History, University of Florida, as well as the teachers, staffs, and students of the museum. I would like to thank my former biology teacher, Prof. Renee B. Paalan of the Biology Department, and Janet S. Estacion, Ph.D. of the Institute of Environmental and Marine Sciences, Silliman University, Dumaguete City, Negros Oriental, Philippines for our invaluable conversations on the biogeography of the Philippines especially on my Negros Ark Hypothesis.

\section{LITERATURE CITED}

Badon, J.A.T., \& J. Jakusch. 2016. New subspecies of Delias diaphana from Panay Island, Philippines (Lepidoptera: Pieridae). Entomologische Zeitschrift 126(1): 25-28.

Baltazar, C.R. 1991. An inventory of Philippine Insects II. Order Lepidoptera (Rhopalocera). University of the Philippines, Los Banos. 399 pp.

Braby, M.F. 2006. Evolution of larval food plant associations in Delias Hübner butterflies (Lepidoptera: Pieridae). Entomological Science 9: 383-398.

Braby, M.F, \& N.E. Pierce. 2006. Systematics, biogeography and diversification of the Indo-Australian genus Delias Hübner (Lepidoptera: Pieridae): phylogenetic evidence supports an 'out-of-Australia' origin. Systematic Entomology 32: 2-25.

Brook, B.W., N.S. Sodhi \& P.K.L. Ng. 2003. Catastrophic extinctions follow deforestation in Singapore. Nature 424: 420-423.

Cayabyab, B.F. 1992. A survey of the Rhopalocera (Lepidoptera) of Mount Makiling. PMCP. UPLB.

Cayabyab, B.F., N.O. Aguilar, C.R. Baltazar \& D.B. Tolentino. 1993. Host plants of Rhopalocera (butterflies) in the Philippines. Philippine Entomologist 9(1): 36-51.

Cayabyab, B.F., R.G. Bayot, \& C.C. Custodio. 1994. A survey of the insect fauna of Mt. Madyaas and Alopijan, Culasi, Antique. Fil-Kulisap 2: 24-29.

Cayabyab, B. F. 2000. A survey of Rhopalocera (Lepidoptera) of Mount Makiling, Laguna, Philippines. Philippine Entomologist 14(1):105-106.

D'Abrera, B. 1982. Butterflies of the Oriental Region: Papilionidae, Pieridae, \& Danaidae. Part 1. Hill House. $244 \mathrm{pp}$.

DeJong, R., \& C.G. Treadaway. 2007. Hesperiidae of the Philippine Islands. In Bauer, E., and Frankenbach, T., Butterflies of the World. Supplement 15: 1-72, 1 color plate. Keltern (Goecke and Evers).

Diakonoff, A. 1967. Microlepidoptera of the Philippine Islands. Smithsonian Institution Press. 484 pp.

Endo, T. \& Y. Kishida. 1999. Day-Flying Moths. Chalcosiinae.Epicopeia. Volume 8. Endless Science Information. Tokyo, Japan.

Jones, A.W. \& R.S. Kennedy. 2008a.Evolution in a tropical archipelago: comparative phylogeography of Philippine fauna and flora reveals complex patterns of colonization and diversification. Biological Journal of the Linnean Society 95: 620-639.

Jones, A.W. \& R.S. Kennedy. 2008b. Plumage convergence and evolutionary history of the Island Thrush in the Philippines. The Condor 110 (1): 35-44.

Müller, C.J., P.F. Matos-Maravi \& L.B. Beheregaray. 2013. Delving into Delias Hübner (Lepidoptera: Pieridae): finescale biogeography, phylogenetics and systematics of the world's largest butterfly genus. Journal of Biogeography 40: 881-893.

Hall, R. 1996. Reconstructing Cenozoic Asia. In Hall, R., \& Blundell, D.J. (editors), Tectonic evolution of Southeast Asia. Geological Society Special Publication. 566 pp.

Hall, R. 2002. Cenozoic geological and plate tectonic evolution of SE Asia and the SW Pacific: computerbased reconstructions, model and animations. Journal of Asian Earth Sciences 20: 353-431.

Hall, R. 2013. The paleogeography of Sundaland and Wallacea since the Late Jurassic. J. Limnol. 72: 1-17.

Heaney, L.R. \& J.C. Regalado. 1998. Vanishing Treasures of the Philippine Rainforest. The Field Museum, Chicago, Illinois. 196 pp.

Heaney, L.R., D.S. Balete, M.L. Dolar, A.C. Alcala, A.T.L. Dans, P.C. Gonzales, N. R. Ingle, M.V. Lepiten, W.L.R. Oliver, P.S. Ong, E.A. Rickart, B.R. Tabaranza \& R.C.B. Utzurrum. 1998. A synopsis of the mammalian fauna of the Philippine Islands. Fieldiana: Zoology New Series 88: 1-61.

MacArthur, R.H., \& Wilson, E.O. 2001. The Theory of Island Biogeography. Princeton University Press.

Nuyda, J.S. \& M. Kitamura. 1994. A new subspecies of Thoressa justini (Hesperiidae: Lepidoptera). Fil-Kulisap 2: 6-7.

Rosenzweig, M.L. 1995. Species Diversity in Space and Time. Cambridge University Press. 436 pp.

Seitz, A. 1908-1928. Die Gross-Schmetterlinge der Erde. 9 Band. Die indo-australischen Tagfalter. Alfred Kernen, Verlag, Stuttgart. $1197 \mathrm{pp}$.

Semper, G. 1886-1892. Die Schmetterlinge der Philippinischen Inseln. Beitrag zur indo-malayischen Lepidopteren-Fauna. Erster Band: Die Tagfalter. Rhopalocera. Wiesbaden (C.W. Kreidel). 380 pp.

Townes, H. \& S. Chiu. 1970. The Indo-Australian species of Xanthopimpla (Ichneumonidae). Memoirs of the American Entomological Institute 14: 1-372.

Treadaway, C.G. \& H.G. Schroeder. 2012. Revised checklist of the butterflies of the Philippines Islands (Lepidoptera: Rhopalocera). Nachrichten des Entomologischen Vereins Apollo Supplementum 20.

Tsukada, E. (Ed.), O. Yata \& K. Morishita. 1985. Butterflies of the South East Asian Islands 2: Pieridae and Danaidae. Plapac Company, Tokyo, Japan. 623 pp. 
Van Balgooy, M.M. J. 1987. A plant geographical analysis of Sulawesi. In: WHITMORE, T. C. (ed.) Biogeographical Evolution of the Malay Archipelago, Oxford: Clarendon Press. pp. 94-102.

Vane-Wright, D. 1990. The Philippines - Key to the Biogeography of Wallacea? In book: Insects and the rain forests of South East Asia (Wallacea), Publisher: London: Royal Entomological Society of London, Editors: W.J. Knight, J.D. Holloway, pp.19-34.

Yagishita, A., S. Nakano \& S. Morita. 1993. An illustrated list of Delias Hübner of the World. Khepera Publishers.

Tokyo. 207 pp. 